\title{
PRICE WARS AND THE STABILITY OF COLLUSION: A STUDY OF THE PRE-WORLD WAR I BROMINE INDUSTRY*
}

\begin{abstract}
Margaret C. Levenstein
Between 1885 and 1914 US bromine producers colluded to raise prices and profits. This collusion was disrupted by price wars. Bromine price wars are compared with the Green/Porter and Abreu/Pearce/ Stacchetti models. Some price wars resulted from the imperfect monitoring problems which motivate these models. Several empirical implications of the APS model are borne out, but the bromine industry's price wars were generally milder than contemplated by APS. More severe price wars were part of a bargaining process, in which firms tried to force renegotiation to a new collusive equilibrium with a different distribution of rents.
\end{abstract}

\section{INTRODUCTION}

ECONOMISTs have long debated the causes and consequences of price wars. Stigler [1964] argued that cartel profits induce cheating or entry. A price war inevitably follows, and collusion disintegrates. Earlier students of industrial organization believed, to the contrary, that the possibility of price wars stabilized collusion (Burns [1936], pp. 27-30). When price wars arose, they were ascribed to exogenous forces disrupting otherwise stable cartels (Stocking and Watson [1951], p. 505). Hearkening back to the older literature, game theorists have argued that price wars may be necessary for cartel stability, and that they occur in response to exogenous shocks (Green and Porter [1984], Abreu, Pearce, and Stacchetti [1986], hereafter APS). Firms engage in price wars to deter cheating, which, in a world of imperfect information, they cannot distinguish from stochastic fluctuations. These "equilibrium price wars" do not reflect the collapse of collusion, but are instead a crucial element in its stability.

These game-theoretic models have not been widely tested, partly because they depend on variables, like beliefs and strategies, that are

* The author acknowledges helpful comments from two anonymous referees, David Arsen, Severin Borenstein, Jeff Borland, Insong Gil, Thomas Iosso, Francine Lafontaine, Kevin Lang, Richard Levin, Nancy Lutz, Paul Milgrom, David Pearce, Matthew Shapiro, David Weiman, Lawrence White, and participants in seminars at the University of Chicago, Stanford University, UCLA, and the Cliometrics Society Summer Conference. She also appreciates the valuable assistance she has received from E. N. Brandt, Barbara Brennan, Delores Goulet, Margaret Lyon, and Kathleen Thomas, all of the Post Street Archives, and from the archivists at the Baker and New England Depository Libraries. All errors, of course, remain her own.

(C) Blackwell Publishers Ltd. 1997, 108 Cowley Road, Oxford OX4 1JF, UK, and 350 Main Street, Malden, MA 02148, USA. 
not observable. In this paper I analyze internal documents from a turn of the century cartel-contracts, correspondence, minutes of negotiations found in the archives of the Dow Chemical Companythat explicitly discuss what industry participants did and did not believe, which strategies they pursued and which they rejected. I use these sources, as well as industry and government publications, to evaluate the role of price wars in stabilizing, and destabilizing, the bromine cartel. ${ }^{1}$

The bromine cartel in the US did use the threat of price wars to provide individual firms with an incentive to participate in the cartel, as suggested by Friedman [1971]. An examination of the historical incidents leading up to each of the six bromine price wars suggests that imperfect monitoring problems - the inability to distinguish between random shocks and real cheating - did contribute to the occurrence of some price wars. A comparison of the qualitative characteristics of price wars with the optimal punishment described by APS finds that in four cases the initial price cut and the duration of the price war were similar, as predicted. However, those price wars were relatively mild, and did not approach the Cournot reversion levels proposed in Green and Porter and Friedman, let alone the more severe punishments contemplated in APS. Two other price wars began right after publicly announced violations of the collusive agreement. These price wars were the result of disagreements among participant firms regarding the distribution of rents generated by collusion. These price wars lasted longer, and prices fell much further. These two price wars are better understood as breakdowns in collusion than as equilibrium punishments.

\section{THE BROMINE POOLS}

Following the US Civil War battlefield discovery that potassium bromide had sedative properties, it quickly became a popular patent medicine, used as a headache remedy and stomach settler. While elemental liquid bromine had been produced commercially in the United States since 1845, demand had been limited to use in daguerreotype photography. In response to the new pharmaceutical demand, sodium chloride salt producers whose underground brine contained bromine began extracting it to make elemental liquid bromine. These firms pumped and heated the brine, extracting sodium chloride and then bromine. Virtually all of this elemental liquid bromine was then sold to one of several large pharmaceutical

\footnotetext{
${ }^{1}$ Detailed citations from these documents can be found in Levenstein [1993]. 
distributors who converted the bromine into potassium bromide salts. These pharmaceutical distributors had national sales networks through which they distributed potassium bromide salts to patent medicine producers, pharmaceutical "jobbers," and pharmacies around the country. In 1880 there were twelve liquid bromine producers, located along the Ohio and Kanawha Rivers. (These firms will be referred to, collectively, as the "Ohio River bromine producers.")

From 1885 to 1902 , competition in the upstream bromine industry was controlled by a pool. The pool was an independent, unincorporated firm with contracts to buy the entire output of every bromine producer. These contracts guaranteed producers a price, and prohibited them from selling to anyone else. The contracts were explicitly conditioned on the participation of all producers. From 1885 to 1891 the pool operated as the National Bromine Company (NBC). From 1892 to 1902 it was run by W. R. Shields. The pool itself had contracts to sell all its bromine to two of the largest pharmaceutical distributors in the country, Mallinckrodt Chemical and Powers \& Weightman (P\&W). The pool also had an agreement with its only potential foreign competition-the Deutsche Bromkonvention-reserving the United States as the exclusive territory of the American producers, in return for its refraining from exporting.

The structure of collusion changed somewhat in 1894, when the downstream firms, Mallinckrodt and P\&W, together contracted directly with a new entrant to purchase all of its output. This firm, the Midland Chemical Company (predecessor of the Dow Chemical Company), introduced a patented technology that integrated the production of liquid bromine and potassium bromide salts, and had significantly larger minimum optimal scale. Midland's contract restricted its output to 100,000 pounds of potassium bromide a year, about twice the equivalent output in bromine of a typical Ohio River firm. Thus, Midland vertically integrated the upstream and downstream production processes, but did not integrate into the distribution function performed by the downstream firms. Shield's contracts with the Ohio River bromine producers and with Mallinckrodt and $\mathrm{P} \& \mathrm{~W}$ remained in force.

The structure of collusion changed more dramatically in 1902 when Dow, having purchased Midland in 1900, refused to renew the contracts Midland had signed with Mallinckrodt and P\&W. It contracted instead with two other distributors whom Dow selected because they had a reputation for not cutting prices. Dow hoped that this selection of outside distributors would prevent a decline in prices despite its decision to operate independently of the pool distributors. Shield's contracts with the Ohio River firms expired and were not renewed, though he continued to act as an intermediary between the Ohio River and Mallinckrodt and P\&W. After a brief price war, an 
Potassium Bromide Prices with price war periods shaded

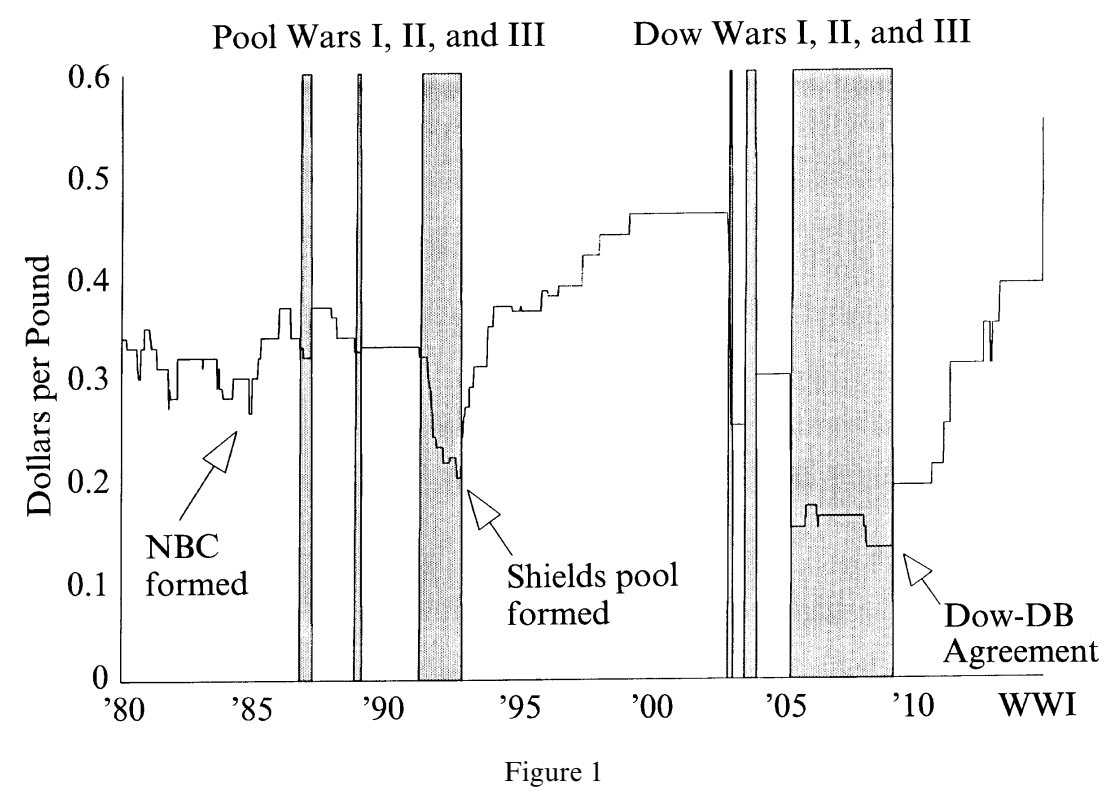

informal collusive arrangement was arrived at, in which all firms promised not to undercut the announced potassium bromide price in the leading industry publication, the Oil, Paint and Drug Reporter. The market division agreement with the Germans was also renewed, but Dow soon began secretly exporting bromides to Europe. In 1905 the Germans retaliated by entering the US market at fifty percent of the going price.

Cooperation was re-established at the end of 1908. Dow and the Germans agreed to set prices for all bromine products jointly and divide world markets. Cooperation within the American market was also reestablished. Dow signed distribution contracts with all the major potassium bromide distributors. These contracts prohibited the distributors from buying bromine from anyone but Dow. For over a year, Dow kept the price of potassium bromide low enough that the Ohio River firms, with their higher production costs, could not profitably sell their bromine. In 1910 Dow contracted with all but one of the Ohio River firms to purchase their entire output on a sliding scale price, based on the published price. Thus Dow recreated the pool structure, but itself acted as the pool, purchasing the entire output of its competitors. The price of potassium bromide rose slowly but steadily until the beginning of World War I (Figure 1).

(c) Blackwell Publishers Ltd. 1997. 


\section{EVALUATING THE SUCCESS OF THE CARTEL}

Before analyzing in more detail the function of price wars in the bromine industry, I address a more basic question. Was collusion successful? Did it restrict output, raise prices, and increase the profits of participating firms? And if so, by how much? An analysis of price trends and a comparison of actual prices with those achievable without cooperation supports the contention of this paper, and the belief of the participants in the industry, that cooperation increased prices and profits. ${ }^{2}$

\section{III(i). Price Trends}

The price of bromine fell continuously after the commencement of commercial production, from six dollars a pound before the Civil War to thirty cents in 1875 . It fell $7 \%$ between 1875 and 1880 , and almost $30 \%$ between 1880 and $1884 .^{3}$ With the establishment of the bromine pool in 1885 , this trend reversed. The price of potassium bromide increased $23 \%$ over the year (Figure 1). ${ }^{4}$ The average price during the NBC pool (1885-1891) was almost ten percent higher than the average price of the previous five year period. When the NBC contracts terminated in 1891, prices returned to their prepool pattern, falling by almost thirty percent (Figure 1). With the establishment of the "Shields pool" in October 1892, prices began a steady upward climb. The average price during the Shields pool was $60 \%$ higher than during the period between the pools. ${ }^{5}$ At the dissolution of the Shields pool in 1902 , the price again fell quite sharply (43.2\% in one month).

\footnotetext{
${ }^{2}$ Because their account books have not survived, direct profit measures for the Ohio River firms and P\&W and Mallinckrodt are not available. Evidence of the Midland Chemical Company's profitability is available but it is difficult to separate profits accruing to cartel prices from those accruing to Dow's patented inventions. Between 1894 and 1900, potassium bromide sold to Mallinckrodt and P\&W was Midland's sole product. Midland issued its first dividend after signing its contract with $\mathrm{P} \& \mathrm{~W}$ and Mallinckrodt in 1894. Midland paid monthly dividends of two to five percent on the par value of its stock over the next six years (Levenstein [1997]). Annual interest rates in the region averaged less than 6.5\% (Davis [1965]).

${ }^{3}$ The price of elemental liquid bromine fell from between six and eight dollars per pound in 1845 to $\$ 4.50$ per pound in 1868 , to $70 \notin$ per pound in 1870 (Haynes [1954], p. 324 and OPDR [1880], p. 655].

${ }^{4}$ After the NBC contracts went into effect, virtually all elemental liquid bromine traded at contract prices. The bromine price quotations in the OPDR were for small lots of bromine purchased from the NBC, not the Ohio River producers. For market prices, I rely on quotations of potassium bromide prices. The average price of potassium bromide between February 18, 1880 and February 11, 1885 was $31.07 \phi$. The comparable price during the NBC, February 18, 1885 to March 4, 1891, was 34.08ф.

${ }^{5}$ The average price of potassium bromide during the Shields pool (October 13, 1892 to October 20,1902) was $40.88 \phi, 60 \%$ above the average price of $24.75 \phi$ from March 11,1891 to October 3,1892 . Since the low price in between the two pools could reflect pricing strategies below competitive prices, the relevant comparison may be to the pre-pool prices of 18801885. The increase associated with the Shields pool would in that case be $31.6 \%$.
}

(c) Blackwell Publishers Ltd. 1997. 
After 1902, Dow's large share of total output, produced at lower cost, makes comparisons with pre-1885 prices less meaningful. The average price after 1902 was lower, during both cooperative and non-cooperative periods, than during the preceding decades. The difference between prices during cooperation and non-cooperation remains. Between 1902 and 1914, the average price during cooperation was almost $75 \%$ higher than during non-cooperative periods. ${ }^{6}$ Similarly, the price increased by almost $50 \%$, from $13 \phi$ to $19 \phi$, on December 21, 1908, when the Dow-Deutsche Bromkonvention agreement took effect. The price trend for the previous three years had been flat or negative (Figure 1). The price remained at $19 \phi$ until May 1910, when the extant Ohio River firms agreed to sell their output to Dow. Immediately thereafter prices began an upward trend that continued until World War I. By 1914, nominal prices had returned, despite decreases in costs, to the levels charged prior to the breakup of the pool in 1902 (Figure 1). ${ }^{7}$

The stability of prices during cooperation was greater than during noncooperative periods. This does not itself indicate that prices were higher, but is consistent with their being set non-competitively (Slade [1991]). The market power exerted by cooperating firms allowed them to ignore small fluctuations in demand or cost. Cooperation may have required infrequent price changes, which had to be coordinated among several, geographically dispersed firms. During non-cooperative periods, firms independently announced prices, increasing the probability that a price change would occur in any given week. Prices changed every 11.5 weeks during noncooperative periods but only every 41.1 weeks during cooperation. The results are similar if the pool (1885-1902) and post-pool (1902-1914) data are separated. During the pools, prices changed every 35 weeks during cooperation, every 6.8 during non-cooperation. After 1902 the pattern remained; prices endured 64.7 weeks during cooperation, 17.5 weeks during non-cooperation.

Average prices were higher during periods of cooperation. Prices increased during cooperation, and fell at its conclusion. Price fluctuations were greater during non-cooperative periods, reflecting the independent price setting behavior of firms. Each and every change in price trends can be explained by a change in the cooperative behavior of the firms in the industry. There is no evidence that changes in demand or cost can explain the observed fluctuations in price.

\footnotetext{
${ }^{6}$ The average price of potassium bromide during non-cooperative periods was $16.8 \phi$. During cooperation it was $29.3 \not$.

${ }^{7}$ All of these results hold if one examines real instead of nominal prices. See the Journal's editorial Web site.

๑ Blackwell Publishers Ltd. 1997.
} 


\section{III(ii). A potassium bromide cost function}

To evaluate more fully the effectiveness of the collusive policies pursued by bromine producers and distributors, I next compare the prices charged during the period studied to counterfactual prices which would have been charged in a competitive regime. This requires estimates of the demand and cost functions for the industry. Unfortunately, I have cost data for neither the Ohio River producers nor the pool's distributors. But Dow's records do provide information on the parameters of its competitors' cost functions. Where there is ambiguity, I use the highest cost parameters so that, if anything, the effect of the cartel is underestimated.

Consistent with discussions among participants in the industry, I assume that upstream firms manufactured liquid bromine with constant marginal cost $\left(M C_{B r}\right)$ and, implicitly, that the bromine producers had a capacity constraint which was determined by plant size and the firm's output of sodium chloride salt. Direct measures of $M C_{B r}$ are not available, but Dow records contain several estimates. These estimates were made at three different times, in considering plans to gain control of Ohio River bromine. In 1896 and 1897 the Midland Chemical Company considered "dead renting" the Ohio River producers, paying them not to produce bromine. Midland attempted to determine the profit they were making on their bromine, so that Midland could offer them an equivalent amount not to produce. Midland knew the price that they received from Shields; the only dispute was the average cost of a pound of bromine. Shields, representing the bromine manufacturers in these negotiations, tried to convince Midland that $M C_{B r}$ was low. Herbert Dow and Henry Cooper, Midland's general manager, opposed the policy of "dead renting" and argued that $M C_{B r}$ was much higher. They argued that $M C_{B r}$ could be as high as $18 \phi$ to $21 \phi$, saying that when prices had fallen much below that the Ohio River firms had stopped producing. J. H. Osborn and B. E. Helman, Midland's vice president and treasurer, respectively, advocated dead renting and often quoted Shield's estimates of $10 \varnothing$ to $12 \notin$ to Dow and Cooper. By 1902, Herbert Dow seems to have accepted that $M C_{B r}$ was about $12 \phi$ per pound. That is the figure he presents to the firm's directors when discussing the implications of Dow's decision to end its cooperation with the pool. $\mathrm{He}$ gives the same estimate to outsiders. The subject is raised again in 1910, when Dow contracted to buy the output of the Ohio River firms. The contract had a sliding scale price for liquid bromine between $11 \phi$ and $19 \notin$ per pound (depending on the selling price of potassium bromide). As the Ohio River firms were not required to produce or sell any amount under these contracts, it is still possible that $M C_{B r}$ was above $11 \%$. So as not to underestimate their costs (and overestimate the effects of the cartel), the calculations presented below use what came to 
be the consensus opinion at the Dow Chemical Company, $12 \phi$ a pound. ${ }^{8}$

I assume that the downstream firms converted bromine into potassium bromide with a Leontief, fixed proportions technology, so the cost function for converting bromine to potassium bromide has the form

$$
M C_{K B r}=\beta P_{\text {bromine }}+\Psi P_{\text {potash }}+\tau
$$

where $\beta$ and $\Psi$ are technical coefficients measuring the liquid bromine and potash contained in a pound of potassium bromide and $\tau$ is the cost incurred converting bromine into a pound of potassium bromide. $P_{\text {bromine }}$ and $P_{\text {potash }}$ are the prices of potash and bromine. The latter was published weekly in the Oil, Paint and Drug Reporter, and its average cost was four cents per pound. While a bromine price was published in the Oil, Paint and Drug Reporter, the relevant price is that paid by Mallinckrodt and P\&W, and specified in pool contracts. I do not have the NBC contract prices, but I do know those in Shields' contracts, and they are used below. ${ }^{9}$ The parameters of the potassium bromide cost function $(\beta, \Psi$ and $\tau)$ are determined from estimates in the Dow correspondence, as well as Dow's own production records and an estimate made, in 1910, of what it would cost Dow to convert Ohio River bromine to potassium bromide.

In the 1896-97 correspondence, Osborn and Helman give, at different times, figures implying a $\beta$ of .7 and .75. In 1910, Shields told Dow that there were 85 pounds of bromine in a hundred pounds of potassium bromide. Herbert Dow's 1910 estimate of the cost to Dow of converting Ohio River bromine assumed a $\beta=.8$. A few months later Dow wrote to the firm's German distributor that there were approximately two thirds of a pound of bromine in a pound of potassium bromide. Since the highest

\footnotetext{
${ }^{8}$ The Ohio River manufacturers all produced bromine as a by-product to the manufacture of salt, so changes in the price of salt might affect the output of bromine. The price of salt was falling over the entire period covered by this study, and salt producers in the Ohio River region were facing increasing competition from new sources of supply (Levenstein [1995]). The primary impact of this decline in salt prices was the exit of several firms over the period. While the calculations below assume that there were twelve producers, by 1910 there were only eight active domestic producers. The combination of low salt prices and low bromine prices during the 1905-1908 price war and Ohio River flooding caused the exit of four producers. Because the production technology required that salt be extracted before bromine, I, like Dow, treat the cost of salt production as a fixed cost. Herbert Dow described the cost of bromine as $12 \phi$ per pound, "plus the loss on salt" (memorandum, 27 January 1902). When the Midland was thinking of "dead renting" the Ohio River bromine plants in 1896 it had discussions with the United Salt Company, an Ohio salt pool, with the hope that it would contribute to the cost of shutting down competitor plants. Acknowledging the ease of entry in salt production, United Salt decided not to pursue the dead renting strategy. The price of salt, and its profit or loss to the Ohio River firms, is never again discussed in Dow documents, suggesting that it had little effect on the marginal output decisions of the Ohio River firms.

${ }^{9}$ Shields purchased the entire stock on hand in 1892 at $14 \phi$ per pound. The Ohio River producers received $16 \phi$ per pound during the first year of the contract, and a $2 \phi$ increase each year (up to $22 \not)$ ).

(c) Blackwell Publishers Ltd. 1997.
} 
estimate of $\beta(.85)$ comes from Shields, who generally had an incentive to understate the costs of making potassium bromide from Ohio River bromine, and since I am attempting to bias the results away from large cartel effects, the cost function below uses that estimate.

The estimates of $\Psi$, the amount of potash in a pound of potassium bromide, in the Dow correspondence vary. Fortunately, Dow's own production records themselves augment these. While Dow's production process differed from that used by its competitors, the physical requirements of potash were approximately the same. As was the case for the other parameters, the lowest estimate of $\Psi, .25$, comes from Osborn. In concurrent correspondence, Helman reports numbers from Shields which imply a $\Psi$ of .44 . These figures are substantially below that implied by Dow's own production records. Production records from Dow's two bromides plants for both 1905 and 1906 each give a $\Psi$ of approximately .58. In Dow's 1910 estimate, he assumed that .57 pounds of potash were necessary to make a pound of potassium bromide from bromine. The conversion cost function rounds these highest estimates up to give a $\Psi$ of .6.

There is even less information available about the parameter $\tau$, the cost incurred by Mallinckrodt and $\mathrm{P} \& \mathrm{~W}$ in converting bromine to potassium bromide. Even Shields probably had no direct information about these costs, and Dow's correspondence with Mallinckrodt and $\mathrm{P} \& \mathrm{~W}$ never mentions their conversion costs. Shields claimed, and most of the 1896-97 Midland Chemical Company correspondence assumed, that this cost was about $1 \phi$ per pound, though Cooper at one point claimed that it might be as high as $5 \varnothing$ per pound. In 1910 Herbert Dow estimated that the labor, packaging, and fuel to convert bromine to potassium bromide would cost Dow about $3.9 \phi$ per pound. Unfortunately, the extant production records do not include any information on Dow's conversion costs once it did purchase Ohio River bromine. Since Dow would have used the same process as Mallinckrodt and $\mathrm{P} \& \mathrm{~W}$, but with less experience in doing so, Dow's projections were probably above the costs of the established distributors. Nevertheless, I round this estimate up and assume a $\tau$ of $4 \varnothing$.

\section{III(iii). A potassium bromide demand function}

For simplicity, I estimate a linear demand function for potassium bromide,

$$
P_{K B r}=\alpha-\Gamma Q_{K B r}+u_{i}
$$

The demand function was estimated using annual data between 1880 and 1914. Weekly data are available for price, but not output. In any case, using annual data minimizes the problems created by speculative demand in response to publicly observed breakdowns in collusion, by averaging 
over periods of collusion and price war during a year. Because I do not have sufficient data to estimate supply behavior, and so estimate demand as part of a system of equations, I instead use instrumental variables to correct for the dependence of $Q_{K B r}$ on $u_{i}$. Annual data on industry output was taken from the US Geological Survey's Mineral Resources of the United States. It is undoubtedly measured with error, as there are discrepancies between measures of output in industry correspondence and in MRUS. Industry correspondence does discuss the MRUS reports, and there does not appear to be any systematic bias in the measure. The potassium bromide price is the average of weekly prices reported in the Oil, Paint and Drug Reporter. These prices were the prices paid by pharmacies and pharmaceutical jobbers to the potassium bromide distributors. I have confidence that OPDR prices do reflect transaction prices as correspondence often referred to quotations in the OPDR. All of the discussion of price changes in the industry correspondence is immediately reflected in OPDR price quotations. I use two instruments which are correlated with $Q_{K B r}$ but should be independent of $u_{i}$ : the price of potash, $P_{\text {potash }}$, and the percentage of the year the industry was colluding, $I_{a v g} . P_{\text {potash }}$ is the annual average of the price announced weekly in the OPDR. $I_{\text {avg }}$ is the annual average of a weekly indicator series, $I_{t}$, which takes the value 1 if the industry is colluding, 0 otherwise. ${ }^{10}$ The series is based on weekly reports in the OPDR and correspondence among industry participants. The estimated demand equation is

$$
P_{K B r}=\underset{(5.496)}{60.551}-\underset{(2.629)}{0.0388} Q_{K B r}
$$

Using the demand equation, I calculate prices, output levels, and profits for counterfactual industry behaviors (Table I). Assuming that there were twelve bromine manufacturers, two distributors, and no potential entry, the very best that all these firms together could do for themselves was to set the price of potassium bromide at $38.6 \notin$ per pound, generating about $\$ 125,000$ profit, to be distributed among the fourteen firms. ${ }^{11}$ The average price of potassium bromide during the pool period (1885-1902), excluding price wars, was $38.57 \phi$. If, instead of organizing the pool, both levels of the industry had played Cournot, the price of potassium bromide would have been 33.5c; if both had played Bertrand, the price would have been 16.6女. The pool structure allowed the firms in the industry to increase

\footnotetext{
${ }^{10}$ If one believed that switching between collusive and price war behavior in this industry was exactly that described in Green and Porter, so that switching was induced by exogenous shocks to demand, $I_{\text {avg }}$ would be dependent on $u_{t}$ and not an appropriate instrument in this regression. However, there is no indication in the correspondence that demand shocks were the source of confusion about whether a firm had cheated.

${ }^{11}$ Either of the Bertrand-Joint Maximization boxes in Table I will give this industry outcome, but the distribution of profits is very different in the two cases.

(c) Blackwell Publishers Ltd. 1997.
} 
TABLE I

Table of Counterfactual Prices and Quantities (QUANTITIES IN THOUSAND POUNDS)

Demand Curve for Potassium Bromide: $P_{K B r}=60.55-0.0388 Q_{K B r}$

Demand Curve for Bromine, if distributors are Bertrand competitors: $P_{B r}=63.7-0.0537 Q_{B}$

Demand Curve for Bromine, if distributors are Cournot competitors: $P_{B r}=63.7-0.0806 Q_{B r}$

Demand Curve for Bromine, if distributors are monopolists: $P_{B r}=63.7-0.1074 Q_{B r}$

\begin{tabular}{|c|c|c|c|c|}
\hline \multirow{5}{*}{$\begin{array}{l}\text { Downstream } \\
\text { (Potassium } \\
\text { Bromide) } \\
\text { Industry } \\
\text { Structure } \\
\text { (2 firms) }\end{array}$} & \multicolumn{4}{|c|}{ Upstream (Bromine) Industry Structure (12 firms) } \\
\hline & & Bertrand & Cournot & $\begin{array}{l}\text { Joint Profit } \\
\text { Maximization } \\
\text { (among upstream } \\
\text { bromine firms) }\end{array}$ \\
\hline & Bertrand & $\begin{array}{lr}P_{B r}= & 12.0 \varnothing \\
P_{K B r}= & 16.6 \phi \\
Q_{B r}= & 962.9 \mathrm{lbs} . \\
Q_{K B r}= & 132.8 \mathrm{lbs} . \\
\mathrm{II}_{B r}= & 0 \\
\mathrm{II}_{K B r}= & 0\end{array}$ & $\begin{array}{lr}P_{B r}= & 16.0 \varnothing \\
P_{K B r}= & 20.0 \varnothing \\
Q_{B r}= & 888.3 \mathrm{lbs} . \\
Q_{K B r}= & 1045.1 \mathrm{lbs} . \\
\mathrm{II}_{B r}= & 35.5 \\
\mathrm{II}_{K B r}= & 0\end{array}$ & $\begin{array}{lr}P_{B r}= & 37.8 \phi \\
P_{K B r}= & 38.6 \varnothing \\
Q_{B r}= & 481.4 \mathrm{lbs} . \\
Q_{K B r}= & 566.4 \mathrm{lbs} . \\
\mathrm{II}_{B r}= & 124.6 \\
\mathrm{II}_{K B r}= & 0\end{array}$ \\
\hline & Cournot & $\begin{array}{lr}P_{B r}= & 12.0 \varnothing \\
P_{K B r}= & 31.2 \varnothing \\
Q_{B r}= & 641.9 \mathrm{lbs} . \\
Q_{K B r}= & 755.2 \mathrm{lbs} . \\
\mathrm{II}_{B r}= & 0 \\
\mathrm{II}_{K B r}= & 110.3\end{array}$ & $\begin{array}{lr}P_{B r}= & 16.0 \varnothing \\
P_{K B r}= & 33.5 \varnothing \\
Q_{B r}= & 592.41 \mathrm{bs} . \\
Q_{K B r}= & 696.71 \mathrm{bs} . \\
\mathrm{II}_{B r}= & 23.7 \\
\mathrm{II}_{K B r}= & 94.1\end{array}$ & $\begin{array}{lr}P_{B r}= & 37.8 \phi \\
P_{K B r}= & 45.9 \phi \\
Q_{B r}= & 320.9 \mathrm{lbs} . \\
Q_{K B r}= & 377.9 \mathrm{lbs} . \\
\mathrm{II}_{B r}= & 82.8 \\
\mathrm{II}_{K B r}= & 39.3\end{array}$ \\
\hline & $\begin{array}{l}\text { Joint Profit } \\
\text { Maximization } \\
\text { (among downstream } \\
\text { bromide distributors) }\end{array}$ & $\begin{array}{lr}P_{B r}= & 12.0 \mathrm{c} \\
P_{K B r}= & 38.6 \mathrm{c} \\
Q_{B r}= & 481.4 \mathrm{lbs} . \\
Q_{K B r}= & 566.4 \mathrm{lbs} . \\
\mathrm{II}_{B r}= & 0 \\
\mathrm{II}_{K B r}= & 124.6\end{array}$ & $\begin{array}{lr}P_{B r}= & 16.0 \varnothing \\
P_{K B r}= & 40.3 \varnothing \\
Q_{B r}= & 444.4 \mathrm{lbs} . \\
Q_{K B r}= & 522.6 \mathrm{lbs} . \\
\mathrm{II}_{B r}= & 17.8 \\
\mathrm{II}_{K B r}= & 106.1\end{array}$ & $\begin{array}{lr}P_{B r}= & 37.8 \varnothing \\
P_{K B r}= & 49.5 \varnothing \\
Q_{B r}= & 240.7 \mathrm{lbs} . \\
Q_{K B r}= & 284 \mathrm{lbs} . \\
\mathrm{II}_{B r}= & 62.1 \\
\mathrm{II}_{K B r}= & 31.3\end{array}$ \\
\hline
\end{tabular}

Note: $Q_{B r}$ is always equal to $.85^{*} Q_{K B r}$ because of the Leontief technology. It would be impossible for the potassium bromide distributors to buy less, and not cost minimizing to buy more.

profits to very nearly the monopoly level. ${ }^{12}$ The pool's exclusive selling contracts also foreclosed competition at the distributor level which might have arisen in the "Cournot-Cournot" scenario where the distributors captured almost $80 \%$ of industry profits.

I can also compare the prices received by the bromine producers during the Shields pool with those under various counterfactual alternatives. If the twelve bromine producers had been able to cooperate perfectly and

\footnotetext{
${ }^{12}$ The total deadweight loss induced by collusion, using the average (non-price war) pool price of $38.6 \notin$, was about $\$ 62,219$ per year. While for the average consumer this amounted to virtually nothing (about one twelfth of a penny per capita in 1900), it is about $28 \%$ of predicted average industry revenues.
}

(c) Blackwell Publishers Ltd. 1997. 
achieve the joint-profit maximizing output level, they would have received a price of $37.8 \notin$ for a pound of their liquid bromine. They did not receive anything close to that under the Shields contracts; the highest price received was $22 \phi$. That was, however, substantially above the price they would have been able to achieve if they simply played Cournot (166). In fact, $16 \phi$ was exactly the price they received in the first year of the Shields contracts, with prices increasing each year as cooperation was maintained.

The Midland Chemical Company similarly profited from the arrangements it made to cooperate with the pool distributors. From 1897 to 1902, Midland (after 1900, Dow) received 25\& for each pound of its potassium bromide, while its average cost per pound was about $8 \notin$. An explicit counterfactual analysis is more difficult in this case, because it is unclear what industry structure would have obtained as the industry adjusted to the new entrant and to its lower cost technology. But with a markup over cost of over 200\%, the contracts with Mallinckrodt and $\mathrm{P} \& \mathrm{~W}$ certainly rewarded Midland generously for its agreement not to try to find out what that structure might be.

After 1902, Dow's average cost increased, as its new contracts required that it produce a wider variety of bromide salts than had previously been the case. Between 1902 and 1905, Dow's bromide cost averaged $10 \frac{1}{4} \phi$. Dow's contract specified that it receive $80 \%$ of the sales price (the OPDR price given the understanding with Mallinckrodt). With an average price of $28.7 \phi$, the price-cost margin during cooperative periods between 1902 and 1905 averaged $12.7 \phi$, more than a $100 \%$ markup over cost. ${ }^{13}$ Collusion was even more successful after the agreement between Dow and the Ohio River was signed in 1910. The average price of potassium bromide was $33.1 \phi$, so that Dow's markup on its cost was over $150 \%$. Some of this profit was shared with the Ohio River producers. Dow bought Ohio River bromine at a price tied to the price of potassium bromide, so that the average price Dow paid the Ohio River producers between 1910 and 1914 was about 17.8ф. Dow's successful entry had eroded their bargaining power, so that the price of bromine was lower than during the Shields pool, but it was still above what they would have received as Cournot competitors.

Finally, while the counterfactual calculations in Table I assume constant costs over time, it is also possible to compare fluctuations in prices with fluctuations in costs. Figure 2 displays the fluctuations in the cost of a pound of potassium bromide during the Shields pool. Fluctuations in cost are driven by changes in the price of potash and annual increases in the

\footnotetext{
${ }^{13}$ In reality, the price-cost margin was greater than this. This calculation compares the average cost of producing all bromides with the price received on potassium bromide. The prices received on other bromides were substantially higher.

๑ Blackwell Publishers Ltd. 1997.
} 
PRICE WARS AND COLLUSION IN BROMINE PRE-WORLD WAR I

Price and Cost of Potassium Bromide

During the Shields Pool

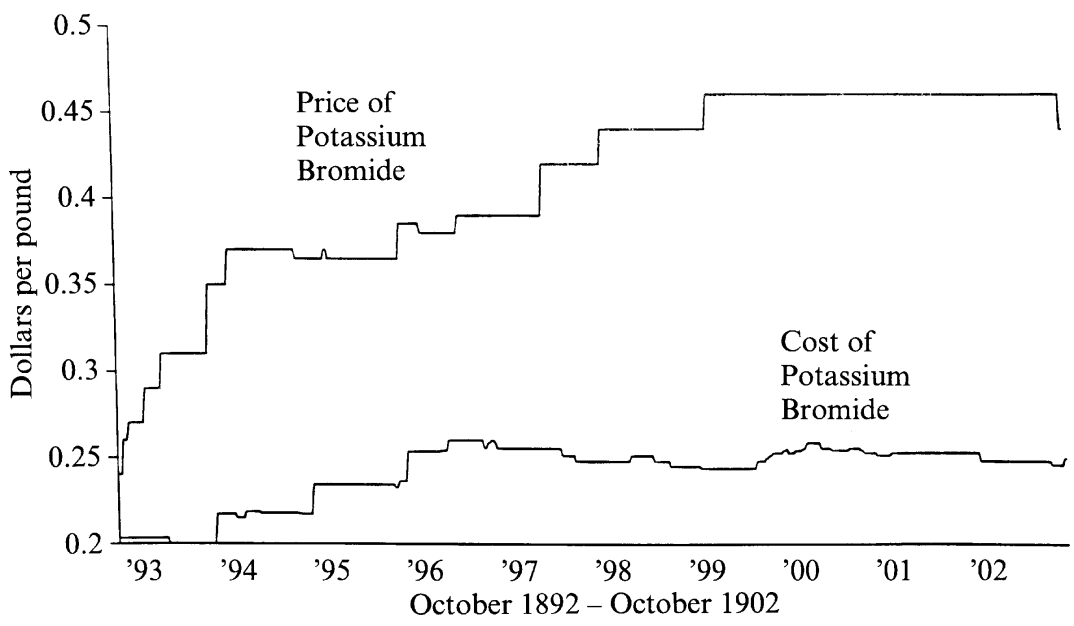

Figure 2

Potassium Bromide Cost Function Using Ohio River Bromine: $M C_{K B r}=\beta_{\text {Pbromine }}+\pi P_{\text {Potash }}+\tau$ Note: $\beta=.85, \pi=.6, \tau=.04$. PBROMINE is the price paid by Mallinckrodt and $\mathrm{P} \& \mathrm{~W}$, as specified in pool contracts. $P_{\text {Potash }}$ is the annual average of weekly prices listed in the Oil, Paint and Drug Reporter.

price of liquid bromine, specified in Shields' contracts. Figure 2 compares the distributors' cost with the market price of potassium bromide. The average price during this period was $40.9 \phi$, while the average cost was 24.16. ${ }^{14}$ The distributors' average markup over cost during the Shields pool was almost seventy percent. ${ }^{15}$ Fluctuations in the cost of potassium bromide do not explain changes in its price. The correlation between changes in price and cost is not even positive $(-0.042)$.

Thus, it is clear that the pool allowed the firms in the industry to

\footnotetext{
${ }^{14}$ The high average price for potassium bromide during the Shields pool may reflect an increase in demand, which would have increased the joint profit-maximizing price. But industry participants much more frequently complained of stagnant demand than mentioned any increase. Thus it is likely that the increased price also reflects the effect of double marginalization on industry price and output levels. Using the prices Shields charged the distributors for liquid bromine, and the potash prices that prevailed over the same period the $M C_{K B r}$ was $24.1 \phi$. That increases the distributors' joint profit-maximizing price to $42.3 \phi$.

${ }^{15}$ A similar comparison could be made between the distributors' cost using Dow bromides. Between 1897 and 1902, Mallinckrodt and P\&W paid Dow 25\& per pound, and also incurred distribution costs. Thus their profit on Dow bromides was somewhat less than on Ohio River bromine.
}

(c) Blackwell Publishers Ltd. 1997. 
increase prices and profits above any reasonable counterfactual noncollusive behavior. For much of the time, they were able to charge prices very close to the monopoly level. Despite the heroic assumptions necessary to compute counterfactual prices we can have confidence in them as they correspond remarkably closely with relevant prices set over the course of the industry's collusive history. For example, when Dow, having agreed to divide up world markets with the Deutsche Bromkonvention, wanted to force the Ohio River producers to contract directly with itself, Dow set the price of the downstream product so that the upstream firms would have no incentive to vertically integrate downstream. Dow set $P_{K B r}$ at $19 \phi$ per pound for almost two years, just below the price $\left(P_{K B r}=20 \notin\right)$ that would have obtained if the Ohio Rivers played Cournot and converted and distributed their output themselves, as some of them attempted to do (the Cournot-Bertrand combination in Table 1).

\section{COMPARING MODELS OF PRICE WARS}

Six price wars disrupted cooperation during the period of this study (Figure 1). Each of these price wars was described as such in the Oil, Paint and Drug Reporter which regularly and explicitly discussed pool activity. Three price wars preceded Dow's entry into the industry (Pool Wars I, II, and III), and three followed (Dow Wars I, II, and III).

Friedman [1971] demonstrated that off-the-equilibrium-path threats of permanent Cournot reversion - a price war-could induce collusion in a sufficiently patient industry. But in Friedman's equilibrium no price war was ever observed. In contrast, Green and Porter [1984] and APS argue that the successful use of punishment threats in an industry where cheating is unobservable will occasionally require their implementation. When firms cannot directly observe deviations from prescribed strategies ("cheating"), they rely on observations of a public variable (e.g. price) whose distribution depends jointly on the actions of each firm (e.g. each firm's output) and a random disturbance. When the public variable falls into a certain range (e.g. prices fall below some $p^{*}$ ) firms revert to punishment behavior (e.g. higher output levels). Since firms cannot distinguish between cheating and low realizations caused by random fluctuations, they must punish to keep incentives intact.

Many aspects of the collusion in bromine resonate with the intuition of this class of games. First, the repeated interaction of firms was crucial to the success of cooperation. The clearest evidence of this is the instantaneous breakdown of cooperation between the Americans and Germans upon the outbreak of war in 1914. The war prevented the Germans from exporting their goods. When the threat to punish cheating in the present with low prices in the future became empty, collusion between the Americans and Germans was no longer sustainable.

๑ Blackwell Publishers Ltd. 1997. 
Second, one agreement between the Dow Chemical Company and the Deutsche Bromkonvention explicitly included "equilibrium punishments." The contract prohibited the parties from exporting into each others' exclusive territory. It provided specific penalties, far short of permanent Cournot reversion, if such exports (or their observational equivalent) did occur. The specified punishment was a simple tit-fortat rule (Axelrod [1984]). It reads,

Should, contrary to agreement, American bromin or its salts arrive in Europe during the continuance of this agreement the Germans are at liberty to send the corresponding quantity of bromin, or its salts, for sale to the North American market ... Should European bromin, or its salts, be shipped to North America the Americans will be at liberty to send to Europe the same quantity of bromin or its salts to the same equivalent as was imported into North America.

While there were instances of bromine products exported into exclusive territory (usually by a third party), this punishment was never implemented. Instead, the parties would agree on a dollar amount to be paid by the presumed violator to the aggrieved party. The penalty was usually equivalent to the presumed profit on the transaction, though in one case of an egregious violation that Dow acknowledged having committed, an additional penalty was imposed.

Third, bromine industry participants could only imperfectly monitor one another. Three kinds of cheating were possible. Bromine producers could sell outside the pool. The distributors could sell bromides below the agreed upon price. Or they could sell bromides in markets that were someone else's exclusive territory. Even if no regular participant in the bromine industry engaged in any of these activities, the storability of bromine meant that third parties could sell goods purchased during an earlier price war. The possibility of such speculative activity increased the difficulty of monitoring compliance. The bromine pool relied on three methods for detecting possible violations: 1) secret, direct observation of plant activity (spying), 2) monitoring fluctuations in customer demand, and 3) monitoring government reports on imports and exports. None of these methods provided perfect information.

Finally, price wars threats were used to induce cooperation with the cartel. Correspondence among industry participants is replete with dire warnings of imminent price wars if the reader did not cooperate. Internal Midland Chemical Company documents are explicit that such threats induced the company's cooperation. Shortly after it began producing bromides, Shields threatened to resume the price war of the previous year if Midland did not agree to sell its entire output to him, on the same terms as the Ohio River producers had. Midland agreed to restrict its output 
and sell only to Mallinckrodt and P\&W, despite Herbert Dow's stated preference to sell independently of the pool.

Similar concerns explain Midland's continued cooperation with the pool. Because its technology had increasing returns, Midland was anxious to increase its output. ${ }^{16}$ Between 1894 and 1896, Midland's output quota increased from 100,000 to 150,000 pounds, far below its capacity of over 350,000 pounds per year. When negotiations began in 1896 to renew the contracts with Midland and the Ohio River producers, Midland considered breaking from the pool. The contract Midland eventually signed limited its annual output to 200,000 pounds. The acceptance of a contract with which it was clearly unsatisfied was the result of its belief that $\mathrm{P} \& \mathrm{~W}$ and Mallinckrodt had accumulated 800,000 pounds of bromine, which they had threatened to dump on the market if Midland did not agree to cooperate. Midland was afraid that the pool would bankrupt the young firm, and so chose instead to cooperate.

Thus in many respects the intuition of Green and Porter and APS is borne out in the bromine case. There are differences between these two models; with the data available, it is possible, in a limited way, to compare their applicability to the bromine case. Green and Porter assumes that firms will revert to one-shot Cournot behavior during price wars, and predicts that price wars will either be permanent or last a fixed number of periods. APS, on the other hand, predicts that firms will switch back and forth between two states: maximal collusion and maximal punishment (potentially more severe than Cournot reversion). ${ }^{17}$ The simplicity of the APS optimal strategy, in which firms play one of two actions, depending only on the prior period realization of the public variable, is appealing both for its analytical elegance and the ease with which such a simple strategy could actually be implemented.

These qualitative characteristics of APS price wars (described in Table II) seem at variance with those observed in the bromine industry. The APS optimal punishment prescribes the same behavior across price wars and the same behavior in every period of the price war. There is, however, substantial variation in the characteristics of the bromine price wars. The initial fall in price ranges from $1 \phi$ to $15 \phi$, or $3 \%$ to $50 \%$ (Table II). The

\footnotetext{
${ }^{16}$ An obvious question is why $\mathrm{P} \& \mathrm{~W}$ and Mallinckrodt did not purchase their entire requirements at a lower price from Midland. First, the Ohio River firms would not immediately exit. Second, $\mathrm{P} \& \mathrm{~W}$ and Mallinckrodt did not want to accept the risk of having a sole supplier of their bromine requirements.

${ }^{17}$ This implies that, in the APS case, the state of the industry follows a first-order Markov process. I conducted several tests of whether the state of collusion in the bromine industry followed a Markov process. While these tests could not reject the hypothesis of a first-order Markov, they were largely inconclusive. More importantly they could not distinguish between a first-order Markov process and a series generated by a much more complex set of strategies in which the probability of a price war was lower immediately following the implementation of a collusive agreement. See the Journal's editorial Web site for details of these test results.

๑ Blackwell Publishers Ltd. 1997.
} 
PRICE WARS AND COLLUSION IN BROMINE PRE-WORLD WAR I

TABLE II

Characteristics of Price Wars Compared

\begin{tabular}{|c|c|c|c|c|c|c|}
\hline Price War & 1886-1887 & 1888 & 1891-1892 & 1902 & 1903 & 1905-1908 \\
\hline $\begin{array}{l}\text { Price war } \\
\text { Name }\end{array}$ & Pool I & Pool II & Pool III & Dow I & Dow II & Dow III \\
\hline $\begin{array}{l}\text { Initial Drop } \\
\text { (c) }\end{array}$ & $2 \phi$ & $1.5 \phi$ & $1 \phi$ & $4 \phi$ & $*$ & $15 \phi$ \\
\hline $\begin{array}{l}\text { Initial Drop } \\
(\%)\end{array}$ & $6.0 \%$ & $4.4 \%$ & $3.0 \%$ & $9.1 \%$ & $*$ & $50 \%$ \\
\hline $\begin{array}{l}\text { Total Drop } \\
\text { (c) }\end{array}$ & $2 \phi$ & $1.5 \phi$ & $13 \phi$ & $19 \phi$ & $*$ & $17 \phi$ \\
\hline $\begin{array}{l}\text { Total Drop } \\
(\%)\end{array}$ & $6.0 \%$ & $4.4 \%$ & $39.4 \%$ & $43.2 \%$ & $*$ & $56.7 \%$ \\
\hline $\begin{array}{l}\text { Duration } \\
\text { (weeks) }\end{array}$ & 22 & 12 & 82 & 6 & 21 & 201 \\
\hline $\begin{array}{l}\text { Weeks to } \\
\text { trough }\end{array}$ & 1 & 1 & 73 & 6 & $*$ & 149 \\
\hline Low price & $32 \phi$ & $32.5 \varnothing$ & $20 \notin$ & $25 \phi$ & $*$ & $13 \phi$ \\
\hline
\end{tabular}

* There was an $18 \notin$ price spread in the quotations for potassium bromide during this Dow War II.

Virtually no quantities were exchanged. This was the only time during the period studied when there was any spread in published price quotations.

Note: All price data are from the Oil, Paint and Drug Reporter. Price wars periods are determined independently of prices, from reports in the OPDR and in internal industry documents.

duration of price wars varies from 6 to 201 weeks, the total drop in price from nothing to almost $60 \%$. This variety may reflect stochastic fluctuations as well as structural change in the industry. But some price wars also display change in behavior within a single price war, with prices spiraling down over the course of the war. In these cases, there was not a switch to a single, commonly understood, worst punishment.

The bromine industry did not use punishments more severe than Cournot reversion. In four of six wars, the price decline was not large enough to reduce the expected present discounted value of the firm's future profit stream below the Cournot reversion level. Only the low prices of Pool III and Dow III wars reached the one-shot Cournot level. ${ }^{18}$ (Compare Tables I and II). Prices never fell below marginal costs. ${ }^{19}$

There are several reasons why the bromine price wars were generally less

\footnotetext{
${ }^{18}$ The low price during Dow War III is $13 \phi$, less than the $20.5 \phi-23.6 d$ range for the Cournot price reported in Table I. But the cost function presented reflects the costs of the Ohio River producers. Dow's costs were much lower so the estimates in Table I no longer apply in 1905, when Dow produced more than half the US output.

${ }^{19}$ This is true as well for Dow War III, when prices are compared to Dow's costs. The low price reached was $13 \phi$, but Dow's marginal cost was less than $10 \phi$.

๑) Blackwell Publishers Ltd. 1997.
} 
severe than those contemplated in the theoretical literature. First, pool members discounted threats which they believed too severe to be credible. Dow dismissed claims that other firms would lower price below their own costs. Dow demanded verification of the inventories Mallinckrodt and $\mathrm{P} \& \mathrm{~W}$ claimed to have ready to dump on the market. Threats designed to support collusion were useful only when credible. When imperfect information led to the implementation of such threats, the ensuing price wars were relatively mild.

Second, the possibility of storing bromine for future use, or for re-sale, increased the costs of price wars. At the end of any price war, the demand faced by pool members remained low until speculative output had been consumed and the market price had reached the pool price. The increased costs of engaging in price wars with storable goods decreased the severity of the optimal price war punishment. This issue was not unique to the bromine industry, however, or even to manufactured goods industries. For example, the JEC's customers, understanding that there was a possibility of a price war among railroad lines, would store their grain in the west in anticipation of a price cut (Ulen [1979], pp. 165-166). Thus the possibility of arbitrage, by customers or third parties, makes it likely that the optimal punishment will be less severe than that contemplated in APS.

Finally, there seems implicit in each price war a reputational cost, such that if other firms believed that some participant had cheated, collusion in the future would be harder to sustain. ${ }^{20}$ This implicit cost may have made it possible for relatively mild punishments to sustain collusion.

Thus, the qualitative characteristics of the bromine price wars seem to differ in important ways from those implied by APS strategies. In particular, equilibrium punishments more severe than Cournot were not used in this industry, for reasons that are common to many other industries. Even in the most effective bromine cartel, established by Dow and the Deutsche Bromkonvention, the written agreement did not pretend to call forth punishments as severe as contemplated in the theoretical literature. In practice, even those punishments were often eschewed as the two parties set up mechanisms to provide themselves with more information about, and therefore, to deter, cheating. They also collected information that allowed them to identify probabilistically the likely perpetrator of any cheating. They then introduced firm-specific punishments, transferring profits from one firm to another, rather than using punishments that lowered profits to the industry as a whole. Although "simple" strategies have analytical elegance, firms in the bromine industry were happy to avail themselves of more complex strategies if necessary to collude successfully.

\footnotetext{
${ }^{20}$ While their model is different from those discussed here, the intuition is similar to that in Kreps, Milgrom, Roberts, and Wilson [1982].

๑ Blackwell Publishers Ltd. 1997.
} 
There were two price wars-Pool III and Dow III-in which prices did fall below Cournot levels (Tables I and II). But this severity seems to have arisen from a difference in the underlying cause of the price wars, rather than in the severity of the optimal punishment. These two price wars were more like Stiglerian collusive breakdowns than "imperfect monitoring" price wars - which arise not from real cheating, but from indistinguishable stochastic shocks. While imperfect information problems exacerbated and lengthened these two price wars, they both began with very public announcements that participants were violating the existing agreement. Dow War III began with a public announcement that the Germans were willing to sell below the pool price, in response to Dow's very real exports to Europe in violation of their understanding with the Germans. Similarly, Pool War III began with a public renunciation of the existing agreement by the Ohio River bromine producers. In both cases, industry participants understood that these announcements were part of a strategy to renegotiate the distribution of rents. In these cases, the limits on the severity of price wars did not obtain as prices fell nearly all the way to marginal costs. These price wars were part of the negotiation of a new collusive arrangement, not a punishment phase that would help to re-establish an existing one. At least in the case of Dow War III, the collusive agreement broke down following a change in the relative costs of firms in the industry. Competition during the price war revealed information about firm costs and staying power, and thus provided the ground rules for the negotiation of a new collusive agreement.

\section{CONCLUSION}

From 1885 to 1914 , participants in the bromine industry colluded, increasing prices and profits. Some of the mechanisms used to sustain this collusion resemble those described in the repeated game literature. As suggested by Friedman [1971], threats of price wars helped sustain collusion. Imperfect monitoring problems contributed to at least some of the six price wars observed. While there are similarities to the punishment strategies proposed by Abreu, Pearce and Stacchetti [1986], the bromine price wars were not as severe as they contemplated. Arbitrage increased the cost and limited the severity of imperfect monitoring price wars. Threats of severe price wars were not considered credible. The most severe price wars seem to have resulted not from monitoring problems, but from the more basic disagreements which inherently plague attempts to collude. The bromine case provides evidence in support of Green and Porter's [1984] claim that the occurrence of price wars is not inconsistent with successful collusion. But if game-theoretic metaphors of equilibrium price 
wars are to have meaning, they must be disguishable from price wars which reflect a breakdown in collusion. The bromine industry provides examples of both.

MARGARET C. LEVENSTEIN

ACCEPTED OCTOBER 1996

Department of Economics,

University of Michigan,

Ann Arbor, MI 48109-1220,

USA

email:maggiel@econ.lsa.umich.edu

\section{REFERENCES}

Abreu, D., Pearce, D. and Stacchetti, E., 1986, 'Optimal Cartel Equilibria with Imperfect Monitoring,' Journal of Economic Theory, 39, pp. 251-269.

Axelrod, R., 1984, The Evolution of Cooperation, Basic Books, New York.

Burns, A. R., 1936, The Decline of Competition: A Study of the Evolution of American Industry (McGraw-Hill, New York).

Davis, L. E., 1965, 'The Investment Market, 1870-1914: The Evolution of a National Market,' Journal of Economic History, 25, pp. 355-399.

Friedman, J. W., 1971, 'A Non-cooperative Equilibrium for Supergames,' Review of Economic Studies, 38, pp. 1-12.

Green, E. J. and Porter, R. H., 1984, 'Non-cooperative Collusion Under Imperfect Price Information,' Econometrica, 52, pp. 87-100.

Haynes, W., 1954, American Chemical Industry: Background and Beginnings v I. (D. Van Nostrand, New York).

Kreps, D., Milgorm, P., Roberts, J. and Wilson, R., 1982, 'Rational Cooperation in the Finitely Repeated Prisoners' Dilemma,' Journal of Economic Theory, 27, pp. 245-252, 486-502.

Levenstein, M. C., 1993, 'Price Wars and the Stability of Collusion: A Study of the Pre-World War I Bromine Industry' DAE Working Paper 50, National Bureau of Economic Research, Cambridge, Mass.

Levenstein, M. C., 1995, 'Mass Production Conquers the Pool: Firm Organization and the Nature of Competition in the Nineteenth Century' Journal of Economic History, 55, pp. 575-611.

Levenstein, M. C., 1997, Accounting For Growth: Competition, Information Systems, and the Creation of the Large Corporation, Stanford University Press, Stanford, CA.

Porter, R. H., 1983, 'A Study of Cartel Stability: The Joint Executive Committee, 1880-1886,' Bell Journal of Economics, 14, pp. 301-314.

Slade, M. E., 1991, 'Market Structure, Marketing Method, and Price Instability,' Quarterly Journal of Economics, 106, pp. 1309-1340.

Stigler, G. R., 1964, 'A Theory of Oligopoly,' Journal of Political Economy, 72, pp. $44-61$.

Stocking, G. W. and Watkins, M. W., 1951, Monopoly and Free Enterprise, Twentieth Century Fund, New York.

Ulen, T. S., 1979, Cartels and Regulation: Late Nineteenth Century Railroad Collusion and the Creation of the Interstate Commerce Commission. Ph.D. dissertation: Stanford University.

(c) Blackwell Publishers Ltd. 1997. 
PRICE WARS AND COLLUSION IN BROMINE PRE-WORLD WAR I

US Census, 1880, 'Chemical Products and Salt,' Report on the Manufactures of the United States at the Tenth Census, GPO, Washington, DC.

US Department of Commerce, 1975, Historical Statistics of the United States: Colonial Times to 1970, Part 1 (GPO, Washington, DC).

US Geological Survey, 1883-1915, 'Bromine,' Mineral Resources of the United States, GPO, Washington, DC.

Bibliographical Note

The Herbert H. Dow Papers are housed in the Post Street Archives, Midland, Michigan.

The Oil, Paint and Drug Reporter was first published in 1871. It has since been superseded by the Chemical Marketing Reporter.

(c) Blackwell Publishers Ltd. 1997. 